\title{
ACID PHOSPHATASE ACTIVITY AND LEAF PHOSPHORUS CONTENT IN SOYBEAN CULTIVARS
}

\author{
Roberto Wagner Cavalcanti Raposoㅜㅜ Takashi Muraoka*; Luiz Carlos Basso³; José Lavres Jr.; \\ Vinicius Ide Franzini² \\ ${ }^{1}$ UFPB/CCA - Depto. de Solos e Engenharia Rural - C.P.64 - 58397-970 - Areia, PB - Brasil. \\ ${ }^{2}$ USP/CENA - Lab. de Fertilidade do Solo - C.P.96 - 13400-970 - Piracicaba, SP - Brasil. \\ ${ }^{3}$ USP/ESALQ - Depto. de Ciências Biológicas - C.P.09 - 13418-900 - Piracicaba, SP - Brasil. \\ ${ }^{4}$ USP/CENA - Programa de Pós-Graduação em Ciências. \\ *Corresponding author <muraoka@cena.usp.br>
}

\begin{abstract}
The phosphate fertilization represents the most costly fraction of soybean crop production. Efficient soybean cultivars for $\mathrm{P}$ absorption and utilization in soils of medium available $\mathrm{P}$ are highly desirable and might contribute for increasing crop production potential. Thirty two soybean [Glycine max (L.) Merr.] cultivars recommended for 'Cerrado' and differing in growth cycle (early, semi-early, semi-late, and late) were grown in a dystrophic Typic Haplustox Cerrado soil to evaluate the acid phosphatase activity, P content in the diagnostic leaf, and shoot biomass. There were differences among the soybean cultivars within all maturation groups in acid phosphatase activity and shoot biomass. The diagnostic-leaf P-content showed significant differences on semi-late and late maturation groups' cultivars. The acid phosphatase activity correlated positively with the plant shoot biomass from semi-early $(r=0.46)$ and late $(r=0.47)$ cultivars, and negatively $(r=-0.40)$ with the $\mathrm{P}$ content in the diagnostic leaf of late maturation cultivars. The occurrence of soybean cultivars with high and low acid phosphatase activity within the same maturation groups indicates the existence of different mechanisms involving P mobilization in the soil and internal plant P remobilization. Key words: enzymatic activity, diagnostic-leaf, maturation group
\end{abstract}

\section{ATIVIDADE DA FOSFATASE ÁCIDA E CONCENTRAÇÃO FOLIAR DE FÓSFORO EM CULTIVARES DE SOJA}

\begin{abstract}
RESUMO: A adubação fosfatada corresponde à fração mais onerosa do custo de produção da cultura da soja. A obtenção de cultivares de soja eficientes na absorção e utilização de fósforo (P) em condição de média disponibilidade deste nutriente pode contribuir para aumentar o potencial produtivo da cultura. Trinta e dois cultivares de soja [Glycine max (L.) Merr.], de ciclo precoce, semiprecoce, semitardio e tardio, recomendados para o cerrado, foram cultivados em Latossolo Vermelho-Amarelo distrófico típico, do cerrado, objetivando avaliar a atividade da fosfatase ácida, concentração de P na folha diagnóstico e biomassa da parte aérea. Ocorreram diferenças entre os cultivares dentro de todos os ciclos de maturação na atividade da fosfatase ácida e na biomassa da parte aérea. Cultivares de ciclos semitardio e tardio apresentaram diferenças significativas quanto à concentração de fósforo na folha diagnóstico. A atividade da fosfatase ácida correlacionou-se positivamente com a biomassa da parte aérea nos cultivares dos ciclos semiprecoce $(r=0,46)$ e tardio $(r=0,47)$ e, negativamente $(r=-0,40)$, com a concentração de $P$ na folhadiagnóstico, nos cultivares do ciclo tardio. A ocorrência de cultivares de soja com alta e baixa atividade da fosfatase ácida dentro do mesmo ciclo de maturação sinalizam a existência de diferentes mecanismos envolvidos na mobilização de P no solo e remobilização interna deste nutriente na planta entre os grupos de cultivares.

Palavras-chave: atividade enzimática, folha diagnóstico, ciclos de maturação
\end{abstract}

\section{INTRODUCTION}

Soybean cultivation in Brazil presents high fertilizer demand, which represents $25 \%$ of all Brazilian fertilizer consumption in agriculture. In addition, phosphorus $(\mathrm{P})$ is the most expensive nutrient as compared to the other nutrients (Câmara, 2000). The majority of Brazilian soils are acid and present high $\mathrm{P}$ retention capacity, with con- sequent low P availability for the plants (Sanchez \& Salinas, 1981). Growers should know the alternatives to reduce production costs, mostly with fertilizers, which correspond to $38 \%$ of the total farm input used in the 'Cerrado' cultivation for a five-year cycle estimation (FNP Consultoria e Comércio, 2003). The utilization of more adapted and efficient soybean cultivars in phosphorus uptake and utilization would certainly contribute for yield increase. 
Phosphorus uptake and utilization efficiency requires a vast and well-distributed class of enzymes known as phosphatases (Duff et al., 1994). The acid phosphatase is a hydrolase which promotes the monoester phosphate hydrolysis, transforming organic phosphate in an inorganic form (Breseghelo et al., 1992). The acid phosphatase activity determination is a fast and sensible test for the P status in the plant, and for this reason, Besford (1979a; 1979b) suggested its utilization as a plant P-deficiency indicator. This author observed in tomatoes, in which the unbalance of 15 nutrients was induced, that only P-deficiency caused an increase in leaf acid phosphatase, hence the suggestion that this enzyme might be used to detect P deficiency in these plants (Besford, 1979c). Several reports in the literature indicate that the acid phosphatase activity is correlated to P-concentrations in tissues of several plant species: Cucumis sativus $L$ (Besford, 1978), Licopersicon esculentum Mill (Besford, 1979a; 1979b), Triticum aestivum L (McLachlan, 1982), Oryza sativa L (Zaini \& Mercado, 1985), Phaseolus vulgaris L. (Breseghelo et al., 1992), Saccharum officinarum L (Silva \& Basso, 1993), Phaseolus vulgaris L and Vigna unguiculata L Walp (Fernandez \& Ascencio, 1994), Cajanus cajan L and Gossypium hirsutum L (Ascencio, 1994), and Bactris gasipaes Kunth (Bovi et al., 1998). However, all of these works tested P doses, without taking into account the acid phosphatase activity, P-uptake and use efficiency for comparison of cultivars and or species, in only one soil fertility situation in terms of soil $\mathrm{P}$ availability.

More efficient $\mathrm{P}$ genotypes usually show lower acid phosphatase activity under P stress situation, reflecting better nutritional condition when compared to inefficient genotypes. Such observations were made in pure lines of sorghum, corn and sorghum hybrids, being inconsistent for other species or among heterozygote genotypes of the same species, probably because of many acid phosphatases types can either be or not be released as exudates by the roots, with specific functions (Furlani \& Machado, 2002). Recently, genes and proteins of the acid phosphatase synthesis in Arabidopsis, tomatoes and lupine were isolated and completely characterized (Vance et al., 2003). Both the Arabidopsis AtACP5 and tomato LePS2 genes are chiefly related to internal Premobilization than in P-uptake, and were both quickly induced, under P deficiency conditions, thus suggesting that the plant molecular responses to external $\mathrm{P}$ concentrations have strict control (Vance et al., 2003). Soybean plants are known to have low or no-secretion roots, that is, are not able to release exudates or present little organic acid exudation in the rhizosphere (Hocking \& Randall, 2001), depending on other agents that induce P mobilization to grow in P limiting environments.

The hypothesis in the present study is that, under medium soil-P availability condition, soybean culti- vars grouped according maturation cycle, would present variation in the leaf acid phosphatase activity, and that this enzyme activity might be used as indicator for soybean breeding programs, attempting to increase the plant efficiency in $\mathrm{P}$ absorption and utilization. In a preliminary research with soybean cultivars cropped in a 'Cerrado's' typical dystrophic Red Yellow Latosol, with low available P (6 to $8 \mathrm{mg} \mathrm{dm}^{-3}$-resin method), there was no success in obtaining enough plant material for analytical determinations, since plants showed poor growth under such severe P stress (data not published), indicating the need for a less limiting soil P level to grow soybean plants. The present work evaluated the leaf acid phosphatase activity, the diagnostic-leaf $\mathrm{P}$ concentration and the canopy shoot biomass, in soybean cultivars of different maturation groups, cultivated in a 'Cerrado's' typical dystrophic Red Yellow Latosol, at medium P soil level.

\section{MATERIAL AND METHODS}

The experiment was carried out in a randomized complete block design, with 32 treatments and three replications, under greenhouse conditions, at Piracicaba, State of São Paulo, Brazil. Seeds of 32 soybean (Glycine $\max (\mathrm{L}$.) Merril) cultivars were inoculated with $1 \mathrm{~mL}$ per pot of Bradyrhizobium japonicum SEMIA 587 and 5019, at sowing. The chosen soybean cultivars were among those most used in the Brazilian 'Cerrado' producing area, representing the early, semi-early, semi-late and late maturation groups (Table 1 ).

A loamy-textured dystrophic Typic Haplustox, previously cultivated with corn and soybeans, was collected at Planaltina de Goiás, State of Goiás, Brazil, an area within the Brazilian central 'Cerrado'. The soil was collected in the $0-20 \mathrm{~cm}$ depth layer, homogenized, air dried and sieved in a $2 \mathrm{~mm}$-mesh screen, forming a composed sample. Soil chemical and physical analysis were made according to methods described by Raij \& Quaggio (1983) and Camargo et al. (1986), respectively, with the following results: $\mathrm{pH}\left(\mathrm{CaCl}_{2}\right)=5.5$; organic matter $=18.3$ $\mathrm{g} \mathrm{kg}^{-1}$; Presin $=20 \mathrm{mg} \mathrm{dm}^{-3} ; \mathrm{K}=2.42 \mathrm{mmol} \mathrm{dm}^{-3} ; \mathrm{Ca}=$ $32.48 \mathrm{mmol}_{\mathrm{c}} \mathrm{dm}^{-3} ; \mathrm{Mg}=13.99 \mathrm{mmol}_{\mathrm{c}} \mathrm{dm}^{-{ }^{-}} ; \mathrm{H}+\mathrm{Al}=$ $24.98 \mathrm{mmol}_{\mathrm{c}} \mathrm{dm}^{-3}$; CEC $=73.78 \mathrm{mmol}_{\mathrm{c}} \mathrm{dm}^{-3}$; sum of bases $=48.89 \mathrm{mmol}_{\mathrm{c}} \mathrm{dm}^{-3} ; \mathrm{V} \%=66,3$; sand $=296 \mathrm{~g} \mathrm{~kg}^{-1}$; silt $=304 \mathrm{~g} \mathrm{~kg}^{-1}$, and clay $=400 \mathrm{~g} \mathrm{~kg}^{-1}$.

Non-perforated plastic pots were filled with 200 $\mathrm{g}$ of soil and each one received four soybean seeds. Seedlings emerged three days after sowing (DAS). Thining at seven days after emergence (DAE) left, one V1-stage (first trifoliolate leaf) plant per pot. Fifteen DAE, $0.4 \mathrm{mg}$ of potassium as $\mathrm{KCl}$ was applied per pot. Water was supplied twice a day, determining the necessary quantity by weighing the pots individually (at 9:00 a.m. and 3:00 p.m.). 
Table 1 - Soybean cultivars characteristics.

\begin{tabular}{|c|c|c|c|}
\hline Cultivar & Cycle & Growth habit & Height \\
\hline & & & $\mathrm{cm}$ \\
\hline M-Soy 6101 & Early & Indeterminate & $105-120$ \\
\hline M-Soy 8001 & Early & Determinate & 75 \\
\hline DM 118 & Early & Determinate & 86 \\
\hline IAC-22 & Early & Determinate & $60-70$ \\
\hline IAC -23 & Early & Determinate & 67 \\
\hline EMGOPA 316 & Early & Determinate & 70 \\
\hline M-Soy 8400 & Semi-early & Determinate & 75 \\
\hline M-Soy 8411 & Semi-early & Determinate & 90 \\
\hline IAC- 18 & Semi-early & Determinate & $70-90$ \\
\hline IAC-24 & Semi-early & Determinate & 72 \\
\hline DM 247 & Semi-early & Determinate & 87 \\
\hline BRS 133 & Semi-early & Determinate & 70 \\
\hline BRS Carla & Semi-early & Determinate & 75 \\
\hline DM 339 & Semi-late & Determinate & 86 \\
\hline DM Vitória & Semi-late & Determinate & 80 \\
\hline IAC -19 & Semi-late & Determinate & $80-100$ \\
\hline IAC PL-1 & Semi-late & Determinate & 80 \\
\hline M-Soy 9350 & Semi-late & Determinate & $90-120$ \\
\hline BRS Milena & Semi-late & Determinate & 100 \\
\hline BRAS 98-5409 & Semi-late & Determinate & 90 \\
\hline MG/BR 46 Conquista & Semi-late & Determinate & 90 \\
\hline BRSGO Bela Vista & Semi-late & Determinate & 85 \\
\hline M-Soy 8866 & Semi-late & Determinate & 90 \\
\hline $98 \mathrm{C} 81$ & Semi-late & Determinate & 92 \\
\hline M-Soy 9001 & Late & Determinate & 90 \\
\hline DM Nobre & Late & Determinate & 96 \\
\hline DM 309 & Late & Determinate & 86 \\
\hline BRSGO Jataí & Late & Determinate & 90 \\
\hline BRAS 9530080 & Late & Determinate & 100 \\
\hline BRAS $97-1368$ & Late & Determinate & 95 \\
\hline BRS Celeste & Late & Determinate & 100 \\
\hline BRAS 97 - 7371 & Late & Determinate & $95-100$ \\
\hline
\end{tabular}

At 46 DAE the in vivo activity evaluation of the acid phosphatase enzyme (E.C.3.1.3.2) was performed according to Besford (1979c). Leaf sampling criterion followed recommendations of Ambrosano et al. (1996), so the third and the fourth recently mature leaf from the apical bud were collected.

Fragments of recently collected leaves (2-mm leaf blades; $100 \mathrm{mg}$ ) were incubated with $8 \mathrm{~mL}$ of $0.25 \mathrm{mmol}$ $\mathrm{L}^{-1}$ p-nitrofenilphosphate (p-NNP) in a $0.1 \mathrm{~mol} \mathrm{~L}^{-1}(\mathrm{pH}$ 4.0) sodium acetate buffer. After 20 minutes of incubation in water-bath at $30^{\circ} \mathrm{C}$ in the dark, $5 \mathrm{~mL}$ of the mixture reaction was interrupted with $2 \mathrm{~mL}$ of a $2 \mathrm{~mol} \mathrm{~L}^{-1}$ $\mathrm{NaOH}$ solution. During the incubation period, the buff- ered p-nitrofenilphosphate substrate (p-NPP) is hydrolyzed by the acid phosphatase resulting in p-nitrophenol (p-NP, yellow in base). Readings were made against a blank sample through optic density in a Klett-Summerson photocolorimeter with a blue filter $\left(\mathrm{n}^{\circ} 42\right)$ and the p-NP quantity was estimated using a p-NP standard curve (the blank sample was also incubated with all reagents except the leaf fragments). The enzyme activity was expressed as $\mu$ moles of hydrolized substrate (p-NPP) per hour, per fresh tissue weight $\left(\mu \mathrm{mol} \mathrm{h} \mathrm{g}^{-1}\right)$.

After the acid phosphatase activity evaluation, leaves remnants were dried in a forced air oven at $65^{\circ} \mathrm{C}$ for 72 hours, weighed, ground and submitted to the chemical analysis for $\mathrm{P}$ concentration determination in the diagnostic-leaf, according to Sarruge \& Haag (1974). The plant shoots were oven dried to obtain the dry weights, which were added to the leaf weights (leaves used in the enzymatic evaluation and $\mathrm{P}$ content determination) to get the total biomass production.

Cultivars were evaluated regarding acid phosphatase activity, diagnostic-leaf P-concentration and biomass production of shoots. Results were submitted to statistical analyses using the SAS - System for Windows 6.11 (SAS Inc., 1996) program, through the GLM procedure. Analysis of variance and the orthogonal decomposition of the treatment degrees of freedom were performed, allowing comparisons among and within each maturation group. When test $\mathrm{F}$ was significant, within each group, the Tukey's test $(\alpha=0.05)$ for multiple mean comparisons was applied to identify differences among cultivars. Correlations between acid phosphatase activity, biomass production and leaf P-concentration were calculated using SAS, through the procedure CORR, calculating the Pearson's correlation coefficients within each maturation group.

\section{RESULTS AND DISCUSSION}

There were differences $(P<0.05)$ among soybean maturation groups, only for the acid phosphatase activity, evidencing different strategies among them for the acid phosphatase synthesis under the tested conditions. Within each maturation group, cultivars differed significantly regarding acid phosphatase activity and biomass production $(P<0.05)$. Differences $(P<0.05)$ were observed in leaf tissue $\mathrm{P}$ concentration only among the semilate and late cultivars (Table 2). Although the substrate $\mathrm{P}$ concentration was considered of medium level (Souza et al., 2002), $P$ concentration in the diagnostic-leaf varied from 0.98 to $1.50 \mathrm{~g} \mathrm{~kg}^{-1}$ among cultivars, what is considered below the adequate critical level for soybean that is 2.5 to $5.0 \mathrm{~g} \mathrm{~kg}^{-1}$ (Ambrosano et al., 1996).

The acid phosphatase activity of early cultivars varied from 4.13 (M-Soy 8001) to $11.69 \mu \mathrm{mol}$ p-NPP h$1 \mathrm{~g}^{-1}$ (DM 118). Cultivars DM 118 and IAC-23 presented 
Table 2 - Acid phosphatase activity, shoot biomass and diagnostic-leaf P-concentration in soybean cultivars, according to maturation groups, cultivated in a dystrophic Red Yellow Latosol under 'Cerrado' (means of three replications).

\begin{tabular}{|c|c|c|c|c|}
\hline Cycle & Cultivars & Acid phosphatase activity & Shoot biomass & Phosphorus \\
\hline & & $\mu \mathrm{mol} \mathrm{h}^{-1} \mathrm{~g}^{-1}$ & g plant $^{-1}$ & $\mathrm{~g} \mathrm{~kg}^{-1}$ \\
\hline & DM-118 & $11.69 \mathrm{a}$ & $2.32 \mathrm{a}$ & $1.23 \mathrm{a}$ \\
\hline & IAC-23 & $10.29 \mathrm{a}$ & $2.20 \mathrm{ab}$ & $1.26 \mathrm{a}$ \\
\hline \multirow[t]{11}{*}{ EARLY } & IAC- 22 & $9.91 \mathrm{ab}$ & $1.79 \mathrm{bc}$ & $1.24 \mathrm{a}$ \\
\hline & EMGOPA-316 & $7.44 \mathrm{bc}$ & $1.51 \mathrm{c}$ & $1.36 \mathrm{a}$ \\
\hline & M-SOY 6101 & $5.86 \mathrm{~cd}$ & $1.99 \mathrm{ab}$ & $1.36 \mathrm{a}$ \\
\hline & M-SOY 8001 & $4.13 \mathrm{~d}$ & $2.12 \mathrm{ab}$ & $1.20 \mathrm{a}$ \\
\hline & Means & $8.22 \mathrm{c}$ & $1.99 \mathrm{~ns}$ & $1.28 \mathrm{~ns}$ \\
\hline & $\mathrm{F}_{\text {EARLY }}$ & 32.79 & 12.31 & 0.76 \\
\hline & C.V.(\%) & 10.68 & 7.33 & 10.67 \\
\hline & DM 247 & $11.80 \mathrm{a}$ & $2.30 \mathrm{a}$ & $1.27 \mathrm{a}$ \\
\hline & IAC-18 & $11.08 \mathrm{ab}$ & $1.79 \mathrm{~b}$ & $1.51 \mathrm{a}$ \\
\hline & BRS Carla & $11.08 \mathrm{ab}$ & $1.98 \mathrm{ab}$ & $1.21 \mathrm{a}$ \\
\hline & IAC-24 & $10.77 \mathrm{ab}$ & $2.04 \mathrm{ab}$ & $1.43 \mathrm{a}$ \\
\hline \multirow{11}{*}{ SEMI-EARLY } & BRS 133 & $9.77 \mathrm{bc}$ & $1.83 \mathrm{~b}$ & $1.33 \mathrm{a}$ \\
\hline & M-SOY 8411 & $9.00 \mathrm{c}$ & $1.70 \mathrm{~b}$ & $1.17 \mathrm{a}$ \\
\hline & M-SOY 8400 & $8.76 \mathrm{c}$ & $2.00 \mathrm{ab}$ & $1.34 \mathrm{a}$ \\
\hline & Means & 10.32 & $1.95 \mathrm{~ns}$ & $1.32 \mathrm{~ns}$ \\
\hline & $\mathrm{F}_{\text {SEMI-EARLY }}$ & 14.58 & 4.55 & 2.09 \\
\hline & C.V. $(\%)$ & 5.08 & 8.27 & 10.70 \\
\hline & IAC-19 & $12.74 \mathrm{a}$ & $2.02 \mathrm{bc}$ & $1.42 \mathrm{ab}$ \\
\hline & BRS Milena & $12.36 \mathrm{a}$ & $2.21 \mathrm{abc}$ & $1.32 \mathrm{abc}$ \\
\hline & DM Vitória & $11.06 \mathrm{ab}$ & $2.30 \mathrm{ab}$ & $1.19 \mathrm{~cd}$ \\
\hline & MG/BR 46 Conquista & $11.03 \mathrm{ab}$ & $2.05 \mathrm{bc}$ & $1.43 \mathrm{a}$ \\
\hline & BRSGO Bela Vista & $10.71 \mathrm{ab}$ & $1.81 \mathrm{c}$ & $1.27 \mathrm{abc}$ \\
\hline \multirow[t]{12}{*}{ SEMI-LATE } & M-SOY 8866 & $10.51 \mathrm{ab}$ & $1.79 \mathrm{c}$ & $1.37 \mathrm{ab}$ \\
\hline & M-SOY 9350 & $10.38 \mathrm{ab}$ & $1.90 \mathrm{bc}$ & $1.35 \mathrm{abc}$ \\
\hline & DM 339 & $9.27 \mathrm{~b}$ & $1.96 \mathrm{bc}$ & $1.25 \mathrm{bc}$ \\
\hline & IAC PL-1 & $9.19 \mathrm{~b}$ & $2.51 \mathrm{a}$ & $1.06 \mathrm{~d}$ \\
\hline & $98 \mathrm{C} 81$ & $9.14 \mathrm{~b}$ & $1.83 \mathrm{c}$ & $1.26 \mathrm{abc}$ \\
\hline & BRAS 98-5409 & $8.83 \mathrm{~b}$ & $1.84 \mathrm{c}$ & $1.42 \mathrm{ab}$ \\
\hline & Means & $10.47 \mathrm{a}$ & $2.02 \mathrm{~ns}$ & $1.30 \mathrm{~ns}$ \\
\hline & $\mathrm{F}_{\text {SEMILATE }}$ & 7.89 & 7.51 & 10.91 \\
\hline & C.V. $(\%)$ & 7.68 & 7.25 & 4.53 \\
\hline & BRAS 97-7371 & $12.08 \mathrm{a}$ & $2.59 \mathrm{a}$ & $0.98 \mathrm{~d}$ \\
\hline & BRS Celeste & $11.12 \mathrm{a}$ & $2.11 \mathrm{ab}$ & $1.29 \mathrm{bc}$ \\
\hline & DM 309 & $8.92 \mathrm{~b}$ & $1.54 \mathrm{~b}$ & $1.50 \mathrm{a}$ \\
\hline \multirow[t]{9}{*}{ LATE } & DM Nobre & $8.82 \mathrm{~b}$ & $1.89 \mathrm{ab}$ & $1.10 \mathrm{~cd}$ \\
\hline & BRAS 97-1368 & $8.22 \mathrm{bc}$ & $2.05 \mathrm{ab}$ & $1.21 \mathrm{c}$ \\
\hline & BRSGO Jataí & $7.91 \mathrm{bc}$ & $1.43 \mathrm{~b}$ & $1.49 \mathrm{ab}$ \\
\hline & M-SOY 9001 & $7.54 \mathrm{c}$ & $2.07 \mathrm{ab}$ & $1.20 \mathrm{c}$ \\
\hline & BRAS 9530080 & $7.26 \mathrm{c}$ & $2.10 \mathrm{ab}$ & $1.24 \mathrm{c}$ \\
\hline & Means & $8.98 \mathrm{~b}$ & $1.97 \mathrm{~ns}$ & $1.25 \mathrm{~ns}$ \\
\hline & $F_{\text {LATE }}$ & 57.40 & 6.22 & 17.48 \\
\hline & C.V. $(\%)$ & 4.40 & 12.72 & 5.88 \\
\hline & $\mathrm{F}_{\text {CICLO }}$ & 51.74 & 0.73 & 2.44 \\
\hline
\end{tabular}

Means followed by the same letter, within each maturation group, do not differ by the Tukey test at 5\%.

higher values $(P<0.05)$ than cultivars EMGOPA 316, MSoy 6101 and M-Soy 8001 (Table 2). Semi-early cultivars differed in the acid phosphatase activity $(P<0.05)$, values varying from 8.76 to $11.80 \mu \mathrm{mol} \mathrm{p}-\mathrm{NPP} \mathrm{h}^{-1} \mathrm{~g}^{-1}$. Cultivars DM 247, IAC-18, BRS Carla, IAC-24 and BRS 133 did not differ from each other in the enzymatic activity, however, M-Soy 8400 and M-Soy 8411 presented lower values (Table 2). Among the semi-late group, the enzymatic activity values varied from 8.83 to $12.74 \mu \mathrm{mol} p-N P P h^{-1}$ $\mathrm{g}^{-1}$. Cultivars IAC-19 and BRS Milena were distinct from DM 339, IAC PL-1, 98C81 and BRAS 98-5409, the last ones with lower acid phosphatase activity (Table 2). Late 
cultivars had the lowest and highest values: 7.26 and 12.08 $\mu$ mol p-NPP $\mathrm{h}^{-1} \mathrm{~g}^{-1}$, respectively. BRAS 7371 and BRS Celeste presented higher values $(P<0.05)$ than the other cultivars, and DM 309 and DM Nobre differed of M-Soy 9001 and BRAS 9530080 (Table 2).

Production of dry matter (DM) within the early maturation group presented cultivars DM 118, IAC-23, M-Soy 8001 and M-Soy 6101 with similar values $(P<$ 0.05), but higher than EMGOPA 316 (Table 2). Within the semi-early maturation group, the DM 247 cultivar differed $(P<0.05)$ from IAC-18, BRS 133 and M-Soy 8411 cultivars (Table 2$)$. There were differences $(P<0.05)$ among the semi-late maturation group, and IAC $\mathrm{PL}^{-1}$ and DM Vitória cultivars had better performance than BRAS 98-5409, 98C81, M-Soy 8866 and BRSGO Bela Vista (Table 2). Regarding the late maturation group, differences $(P<0.05)$ were observed among cultivars, and BRAS 97-7371 showed higher DM yield than cultivars DM 309 and BRS Jataí, but did not differ from others in the same group (Table 2).

No differences were observed $(P<0.05)$ regarding leaf-diagnostic $\mathrm{P}$-concentration among cultivars in the early maturation group, as well as for the ones of the semi-early group (Table 2$)$. However, differences $(P<$ 0.05 ) were observed within the semi-late group; IAC PL1 and DM Vitória showed lower leaf P. The other cultivars did not differ from each other, presenting higher leaf P, but always below the critical level for soybeans (2.5 $\mathrm{g}$ $\mathrm{kg}^{-1}$ ) according to Ambrosano et al. (1996). Late soybean cultivars differed in diagnostic-leaf P: DM 309 and BRSGO Jataí presented the highest values (1.50 and 1.49 $\mathrm{g} \mathrm{kg}^{-1}$ respectively) and BRAS 97-7371 and DM Nobre cultivars, the lowest values ( 0.98 and $1.10 \mathrm{~g} \mathrm{~kg}^{-1}$, respectively) (Table 2). It was also observed that all late cultivars presented leaf $\mathrm{P}$ concentrations below the critical level previously cited. Although correlation coefficients between biomass and leaf $\mathrm{P}$ were negative for early ( $\mathrm{r}=$ $-0.38)$ and semi-early cultivars $(r=-0.18)$, they were nonsignificant. A negative relationship between biomass and leaf $\mathrm{P}$ concentration was observed within the semi-late $(r=-0.49)$ and late $(r=-0.74)$ maturation groups. As plant biomass increased there was a decrease in leaf $\mathrm{P}$ concentration, characterizing a nutrient dilution effect in the tissues (Jarrel \& Beverly, 1981).

Differences in the values for root acid phosphatase activity do not always evidence plant differences regarding $\mathrm{P}$ uptake and utilization efficiency (Furlani \& Machado, 2002). Studies with genetic markers in bean genotypes, one efficient and another inefficient, proved that the gene locus for root acid phosphatase was not associated to the loci for P uptake and utilization efficiency (Yan et al., 2001). High root enzymatic activity, however, can result in plant stress signals for the need of higher external P supplies for plant development (Furlani \& Machado, 2002).
Taking as example the data on the late cultivars BRAS 7371 and DM Nobre, it was observed higher leaf acid phosphatase activity in BRAS 7371 than in DM Nobre, despite their similar biomass and leaf tissue $P$ concentration. I can be thus inferred that BRAS 7371 cultivar should probably be more stressed than DM Nobre (Table 2). On the other hand, the early cultivar M-Soy 8001 presented low leaf acid phosphatase, correspondent to about one third of the value reached by DM-118, but no differences $(P<0.05)$ were found between the two cultivars regarding biomass production and leaf P-concentration. These are evidences that other mechanisms than acid phosphatase activity, such as root exudation of organic acids, enhance P uptake and utilization efficiency (Hocking \& Randall, 2001; Vance et al., 2003), and that should be studied.

Soybeans are well known as non-secreting or poor organic acid root-secreting plants (Hocking \& Randall, 2001), depending on other factors that enhance P mobilization under P-limiting environments. Such considerations lead to speculations about the existence of genetically different cultivars regarding the organic acid secretion, what would explain the variation regarding acid phosphatase activity within the same maturation group.

The simple linear correlation analysis between the acid phosphatase activity and shoot biomass within each soybean maturation group showed that the enzyme activity was directly proportional $(P<0.05)$ to the produced shoot biomass of semi-early $(\mathrm{r}=0.46 ; \mathrm{N}=21)$ and late $(\mathrm{r}$ $=0.47 ; \mathrm{N}=24$ ), indicating that semi-early and late cultivars with higher biomass yield also presented higher phosphatase activity at the same P level condition (Table 3). At any rate, results of several studies show that the acid phosphatase activity is inversely proportional to the dry matter production under P deficiency (McLachlan, 1982; Breseghelo et al., 1992; Kummerová \& Buresová 1990 cited by Furlani \& Machado, 2002). There is no reference in the literature concerning the relationship between the acid phosphatase activity and biomass production among soybean cultivars grouped by maturation cycles and evaluated at only one soil P level, but reports about these relations with sorghum and corn are found (Camacho \& Malavolta, 2000; Furlani et al., 1984; Kummerová \& Buresová, 1990; cited by Furlani \& Machado, 2002).

The biomass production correlated negatively $(P$ $<0.01$ ) with the diagnostic-leaf P-concentration in semilate $(\mathrm{r}=-0.49 ; \mathrm{N}=33)$ and late $(\mathrm{r}=-0.74 ; \mathrm{N}=24)$ cultivars (Table 3 ). Plants with higher biomass production presented lower leaf P-concentration, mostly in the semi-late and late soybean maturation group, characterizing the tissue P dilution effect (Jarrell \& Beverly, 1981).

The acid phosphatase activity presented negative correlation $(P<0.05)$ with leaf $P$ concentration $(r=-0.40$; $\mathrm{N}=24$ ) within the late soybean cultivars group (Table 3 ), indicating that a decrease in the diagnostic-leaf P- 
Table 3 - Simple linear correlation coefficient estimates between leaf acid phosphatase activity, and shoot biomass and diagnostic-leaf P concentration of soybean cultivars according to maturation group.

\begin{tabular}{|c|c|c|c|}
\hline Maturation Group & Variable & Acid phos. activity & Shoot biom. \\
\hline \multirow{4}{*}{ Early } & Shoot biom. & $0.24 \mathrm{~ns}$ & \\
\hline & & $(P=0.32)$ & \\
\hline & Leaf P conc. & $-0.08 \mathrm{~ns}$ & $-0.38 \mathrm{~ns}$ \\
\hline & & $(P=0.75)$ & $(P=0.11)$ \\
\hline \multirow{4}{*}{ Semi-Early } & Shoot biom. & $0.46 *$ & \\
\hline & & $(P=0.04)$ & \\
\hline & Leaf $\mathrm{P}$ conc. & $0.17 \mathrm{~ns}$ & $-0.18 \mathrm{~ns}$ \\
\hline & & $(P=0.44)$ & $(P=0.42)$ \\
\hline \multirow{4}{*}{ Semi-Late } & Shoot biom. & $0.11 \mathrm{~ns}$ & \\
\hline & & $(P=0.51)$ & \\
\hline & Leaf $\mathrm{P}$ conc. & $0.30 \mathrm{~ns}$ & $-0.49 * *$ \\
\hline & & $(P=0.09)$ & $(P=0.004)$ \\
\hline \multirow{4}{*}{ Late } & Shoot biom. & $0.47 *$ & \\
\hline & & $(P=0.02)$ & \\
\hline & Leaf $\mathrm{P}$ conc. & $-0.40 *$ & $-0.74 * *$ \\
\hline & & $(P=0.05)$ & $(P=0.0001)$ \\
\hline
\end{tabular}

ns = non significant; ${ }^{*}, * *$, significant at 5 and $1 \%$, respectively.

concentration induced increase in the enzyme activity. No significant correlation in the other soybean maturation groups was observed (Table 3). Young developing plants and P-stressed plants usually show higher acid phosphatase activity, which guarantees $\mathrm{P}$ supply from older tissues by hydrolyzing $\mathrm{P}$ from organic forms to inorganic $\mathrm{P}$, and remobilizing it to the apical growing parts (Duff et al., 1994; Furlani \& Machado, 2002). Soybean cultivars with higher biomass production, reduce acid phosphatase activity but keep the same leaf tissue $\mathrm{P}$ concentration. On the other hand, cultivars with higher biomass production, increase acid phosphatase activity, and maintain the same leaf tissue P concentration within the same maturation group. Results of this work are evidence that differentiated soybean plant mechanisms are involved in the soil $\mathrm{P}$ acquisition and in the internal P-remobilization, and being the need for further biochemical and molecular studies to characterize the genes responsible for these mechanism controls.

\section{ACKNOWLEDGEMENTS}

To IAEA (International Atomic Energy Agency) ( CRP Project BRA-10954/RB) for financial support and to CNPq for fellowships granted to TM and VID.

\section{REFERENCES}

AMBROSANO, E.J.; TANAKA, R.T.; MASCARENHAS, H.A.A.; RAIJ, B. van; QUAGGIO, J.A.; CANTARELLA, H. Leguminosas e oleaginosas. In: RAIJ, B. van (Ed.) Recomendações de adubação para o Estado de São Paulo. Campinas: Instituto Agronômico de Campinas; Fundação IAC, 1996. p.187-203.
ASCENCIO, J. Acid phosphatase as a diagnostic tool. Communications in Soil Science and Plant Analysis, v.25, p.1553-1564, 1994.

BESFORD, R.T. A phosphatase as a potential indicator of phosphorus status of the glasshouse cucumber (Cucumis sativus). Journal of the Science, Food and Agriculture, v.29, p.87-91, 1978.

BESFORD, R.T. Quantitative aspects of leaf acid phosphatase activity and the phosphorus status of tomato plants. Annals of Botany, v.44, p.153161, 1979a.

BESFORD, R.T. Phosphorus nutrition and acid phosphatase activity and the leaves of seven plant species. Journal of the Science, Food and Agriculture, v.30, p.281-285, 1979b.

BESFORD, R.T. Nutrient imbalances in tomato plants and acid phosphatase activity in the leaves. Journal of the Science, Food and Agriculture, v.30, p.275-280, 1979c.

BOVI, M.L.A.; BASSO, L.C.; TUCCI, M.L.S. Avaliação da atividade "in vivo" da fosfatase ácida e do crescimento de progênies de pupunheira cultivadas em duas doses de nitrogênio e fósforo. Revista Brasileira de Ciência do Solo, v.22, p.427-434, 1998.

BRESEGHELO, M.L.; OLIVEIRA, I.P.; THUNG, M.D.T. Resposta de cultivares de feijão ao teste de fosfatase ácida. Pesquisa Agropecuária Brasileira, v.27, p.647-654, 1992.

CÂMARA, G.M.S. (Ed.) Soja: tecnologia da produção II. Piracicaba: ESALQ, LPV, 2000. 450p.

CAMARGO, L.C.; MONIZ, A.C.; JORGE, J.A.; VALADARES, J.M.A.S. Métodos de análise química, mineralógica e física de solos do Instituto Agronômico de Campinas. Campinas: IAC, 1986. 94p. (Boletim Técnico, 106)

DUFF, S.M.G.; SARATH, G.; PLAXTON, W.C. The role of acid phosphatases in plant phosphorus metabolism. Physiologia Plantarum, v.90, p.791-800, 1994.

FERNANDEZ, D.S.; ASCENCIO, J. Acid phosphatase activity in bean and cowpea plants grown under phosphorus stress. Journal of Plant Nutrition, v.17, p.229-241, 1994.

FNP CONSULTORIA \& COMÉRCIO. Agrianual 2003 - Anuário da agricultura brasileira. São Paulo, 2003. 544p. Falta citação no texto.

FURLANI, A.M.C.; MACHADO, C.T.T. Variabilidade e herança da eficiência na absorção e utilização de nutrientes em ambientes marginais, em germoplasma de soja, trigo, arroz e milho. In: ALVAREZ V, V.H.; SCHAEFER, C.E.G.R.; BARROS, N.F.; MELLO, J.W.V.; COSTA, L.M. (Ed.). Tópicos em ciência do solo. Viçosa: SBCS, 2002. cap.7, p.337391.

Sci. Agric. (Piracicaba, Braz.), v.61, n.4, p.439-445, July/August 2004 
HOCKING, P.J.; RANDALL, P.J. Better growth and phosphorus nutrition of sorghum and wheat following organic acid secreting crops. In: HORST, W. J.; SCHENK, M.K.; BÜRKERT, A. et al (Ed.) Plant nutrition - food security and sustainability of agro-ecosystems through basic and applied research. Dordrecht: Kluwer Academic, 2001. p.548549. Completar editors.

JARRELL, W.M.; BEVERLY, R.B. The dilution effect in plant nutrition studies. Advances in Agronomy, v.34, p.197-224, 1981.

McLACHLAND, K.D. Leaf acid phosphatase activity and the phosphorus status of field-grown wheat. Australian Journal of Agriculture Research, v.33, p.453-464, 1982.

RAIJ, B. van; QUAGGIO, J.A. Métodos de análises de solos para fins de fertilidade. Campinas: Instituto Agronômico, 1983. 39p. (Boletim Técnico, 81)

SANCHEZ, P.A.; SALINAS, J.G. Low input technology for managing Oxisols and Ultisols in tropical America. Advances in Agronomy, v.34, p.280-406, 1981.

SAS INSTITUTE. SAS/STAT user's guide. version 6.11. 4.ed. Cary: SAS, 1996. v.2, 842p.

SARRUGE, J.R.; HAAG, H.P. Análises químicas em plantas. Piracicaba: ESALQ, Depto. Química, 1974. 56p.
SILVA, F.C. da; BASSO, L.C. Avaliação da atividade in vivo da fosfatase ácida da folha na diagnose da nutrição fosfórica em cana-de-açúcar. Revista Brasileira de Ciência do Solo, v.17, p.371-375, 1993.

SOUZA, D.M.G.; LOBATO, E.; REIN, T.A. Adubação com fósforo. In: SOUZA, D.M.G.; LOBATO, E. (Ed.) Cerrado: correção do solo e adubação. Planaltina: Embrapa Cerrados, 2002. cap.6, p.147-168.

VANCE, C.P.; UHDE-STONE, C.; ALLAN, D.L. Phosphorus acquisition and use: critical adaptations by plants for securing a nonrenewable resource. New Phytologist, v.157, p.423-447, 2003.

YAN, X.; LIAO, H.; TRULL, M.C.; BEEBE, S.E.; LYNCH, J.P. Induction of a major leaf acid phosphatase does not confer adaptation to low phosphorus availability in common bean. Plant Physiology, v.125, p.1901-1911, 2001.

ZAINI, Z.; MERCADO, T.T. Phosphorus and phosphatase activity of rice seedling. I Levels of phosphorus and phosphatase activity of the roots. The Philippine Agriculturist, v.68, p.211-216, 1985.

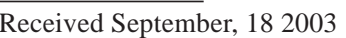

Accepted May 21, 2004 